\title{
The consequences of REIT index membership for return patterns
}

\author{
Andrey Pavlov ${ }^{\mathrm{A}}$, Eva Steiner ${ }^{* \mathrm{~B}}$ and Susan Wachter ${ }^{\mathrm{C}}$

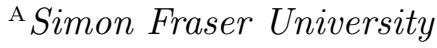

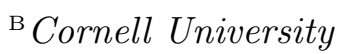 \\ ${ }^{\mathrm{C}}$ University of Pennsylvania
}

\begin{abstract}
The impact of stock market index membership on REIT stock returns is unclear. Returns may become more like those of other indexed stocks and less like those of their underlying properties. Taking advantage of the inclusion of REITs in major S\&P indexes starting in 2001, we find that shared index membership significantly increases the correlation between REIT returns. However, index membership also enhances the link between REIT returns and the underlying real estate, consistent with improved pricing efficiency. REIT investors appear to be able to enjoy improved visibility associated with index membership and increased exposure to underlying real estate markets.
\end{abstract}

Key words: Real estate investment; index membership; REITs.

* Corresponding author: Cornell University, 465B Statler Hall, Ithaca, NY 14853, Telephone: +1 (607) 255-6697, Email: ems457@cornell.edu

Andrey Pavlov acknowledges financial support from the Social Science and Humanities Research Council of Canada. Susan Wachter acknowledges financial support from the Zell Lurie Real Estate Center at the Wharton School of the University of Pennsylvania. 


\section{Introduction}

Our primary goal in this study is to assess whether and how REIT stock market index membership impacts the association between the returns of REITs that are part of the same index and the ability of those REITs to track the performance of their underlying real estate assets. The literature on corporate stocks suggests that improved stock visibility associated with index membership may well increase the number of investment funds allocating capital to REITs and also that the inflows and outflows of that capital are highly correlated (Goetzmann and Massa, 2003). Therefore, the return patterns of firms that form part of an index or industry group may become more correlated to other firms in that group and detach from non-index peers (Cremers, Petajisto, and Zitzewitz, 2013; Greenwood and Sosner, 2007; Wurgler, 2011).

Increased co-movement with firms in the same index and detachment from non-index peers induced by this liquidity effect of index-linked investment may imply that REITs become more like other (financial) stocks in the index and less like real estate as reflected by detachment in their pattern of returns from non-index peers. If so, the liquidity effect in the REIT sector as a whole may undermine the pricing efficiency related to the firm-specific underlying property fundamentals. Which effect dominates is an empirical question.

The existing finance literature on the economic consequences of index membership does not offer clear predictions on these potential outcomes. That is because REITs face a unique situation: They own assets that are actively traded in a secondary market, where direct ownership of those assets is a real alternative for investors seeking exposure to real estate. In REITs therefore, index membership may not only make index members behave more like each other and less like their non-index publicly traded peers. Rather, there is an additional dimension to the question, in the sense that index membership may also impact the association between REITs and the performance of the underlying properties that they own.

Key to the empirical identification of these effects is determining a significant event in the treatment of REITs as part of major stock market indexes or segments. Here we use 
the decision by S\&P to consider REITs in their main stock market indexes in $2001 .^{1}$

To address the above issues, we employ a novel empirical approach. The association between REIT returns and the performance of the underlying properties is typically examined by estimating REIT returns as a function of a proxy measure for the return on the underlying properties. ${ }^{2}$ Instead of relying on these proxies, we develop measures of similarity or difference in exposure to either an underlying property type or geographic area across pairs of REITs and through time. We use these measures of similarity or difference in exposure as a predictor for the pairwise correlation patterns between firms. If property exposure affects REIT returns, then stock returns for REITs with similar property type and geographic exposure are likely to be more similar than stock returns for REITs with different property type or geographic exposure. This approach allows us to assess the effect of property fundamentals, in terms of sector and geography, on return patterns without requiring the explicit measurement of the returns generated by properties in a certain sector or region.

We use this approach to evaluate the relative impact on joint return patterns of a set of indicator variables reflecting whether or not any two REITs are part of one of the major S\&P indexes, or whether any one of two REITs in a pair is part of an index, relative to the impact of the fundamentals that characterize the underlying portfolio of the properties held by the REITs in terms of property sector and geographic exposure. In order to isolate the effects of interest, we also control for firm-level fundamentals,

\footnotetext{
1 This decision marked the inception of a period during which REITs were increasingly integrated into stock market indexes and industry classification systems gave growing recognition to real estate as a distinct industry or sector, e.g. by the Office of Management and Budget with respect to the North American Industry Classification System in 2007 and by Morningstar with respect to the Morningstar Global Equity Classification Structure in 2010. The decision by S\&P Dow Jones Indices and MSCI Inc. to create a new Real Estate sector under the Global Industry Classification Standards (GICS) in 2016 is the most recent in this string of events. As such, the 2001 decision reflects a significant structural break in the history of REITs and their return patterns (Case, Yang, and Yildirim, 2012) that has been successfully employed for research purposes before (Ambrose, Lee, and Peek, 2007). As a result, we focus on REIT returns from 2001 onwards.

2 Available measures of the underlying property returns are fraught with difficulty. Appraisal-based measures suffer from smoothing (Blundell and Ward, 1987; Quan and Quigley, 1991), requiring ever-more sophisticated unsmoothing techniques (Bond and Hwang, 2003, 2007; Cho, Kawaguchi, and Shilling, 2003; Cho, Hwang, and Lee, 2014; Edelstein and Quan, 2006; Fisher, Geltner, and Webb, 1994; Geltner, 1991, 1993). Transaction-based price indexes (Fisher, Geltner, and Pollakowski, 2007; Gatzlaff and Holmes, 2013; Sirmans and Slade, 2012) present a possible alternative but need to be interpreted with caution as they may be based on thin trading activity (Haurin, 2005; Miles, Hartzell, Guilkey, and Shears, 1991) or price observations may be biased by sentiment (Clayton, Ling, and Naranjo, 2009).
} 
especially those stock characteristics that determine whether a firm meets the inclusion criteria for the $\mathrm{S} \& \mathrm{P}$ indexes in the first place, alongside cross-sectional and time-series fixed effects to capture broad, unobservable influences.

We are not the first to study the fundamental drivers of joint return patterns in REITs. Liow, Zhou, and Ye (2015) study the pairwise correlations between international listed real estate securities indexes as a function of market-wide fundamentals. Alcock and Steiner (2016) study the firm-level drivers of the correlation between individual REIT stocks and the general stock market. However, these studies do not examine pairwise correlations between individual REIT firms, and they do not assess the effects of index membership in comparison to the underlying property-level fundamentals.

For the period 2001 to 2015, we find that the returns of REITs that are part of the same index are significantly more correlated than the returns from REITs that are not part of any index. This finding adds to the evidence of increased co-movement between firms with shared index membership that has been established for general industrial firms (Cremers, Petajisto, and Zitzewitz, 2013; Greenwood and Sosner, 2007; Wurgler, 2011). We also find that the returns of firm pairs where only one firm is part of an index are more correlated than the returns from pairs where no constituent firm is part of an index. This latter finding confirms earlier evidence on spillover effects from index-firms to non-index firms (Ambrose, Lee, and Peek, 2007).

We further find that, after controlling for index membership, the property type exposure of a REIT remains a significant predictor for the subsequent evolution of joint returns, where the correlation between returns is significantly reduced when the firms focus on different property sectors. We find similar evidence for geographic exposure. Further, we find that property type and geographic exposure remain significant predictors of joint return patterns when conditioning on joint index membership. Our findings suggest that differences in the underlying property fundamentals of the firms continue to reduce their return correlation even when they are part of the same stock market index. We also document that index membership increases the impact of property type and geographic exposure on returns, consistent with improved pricing efficiency. Lastly, we find no evi- 
dence for a convergence in firm investment or financing policy as a result of shared index membership, suggesting that the return effects we document are related to asset and management valuation rather than convergence of managerial behaviors.

Our work makes three contributions. First, we contribute to the debate about the extent to which REITs reflect the performance of the stock market relative to the underlying properties. Our findings provide evidence of an immediate and lasting impact of property fundamentals on the joint return patterns of REITs. Second, we are, to our knowledge, the first to explicitly quantify the effect of property type and geographic exposure on REIT dependence patterns and to show the effect of leverage on pairwise correlations across individual firms. Finally, we contribute to the literature on the consequences of REIT index membership. We are, to our knowledge, the first to compare the relative influence of index membership versus underlying property fundamentals on the joint return patterns of REITs.

In practical terms, our results allow us to address the potential economic consequences of the recent announcement by S\&P Dow Jones Indices and MSCI Inc. to create a new Real Estate sector under the Global Industry Classification Standards (GICS). Real Estate, and with it the Equity Real Estate Investment Trust (REIT) industry, is to be removed from the Financials sector and promoted to its own sector. ${ }^{3}$ The REIT industry has hailed this announcement as "the biggest development to hit the sector in 15 years", referring to the inclusion of REITs in the S\&P stock market indexes in $2001 .^{4}$ Our findings suggest that REIT investors may be able to enjoy the benefits of real estate being a separate GICS sector in terms of improved visibility and pricing efficiency and the benefits of diversification associated with the exposure to the underlying properties in terms of property sectors and geographic regions.

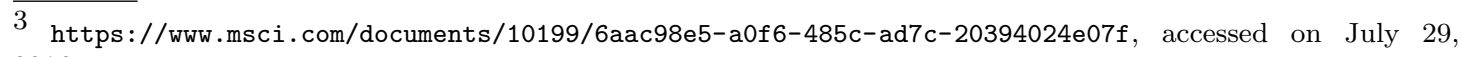
2016.

4 https://www.reit.com/news/reit-magazine/may-june-2016/effects-upcoming-gics-classificationreit-industry, accessed on July 29, 2016.
} 


\section{Related literature}

The objective of our study is to evaluate the relative influence of a financial factor, namely, shared stock market index membership, and a real factor, that is, the exposure to the same underlying property sector and geography, on the pairwise co-movement of REIT returns. As a result, our study connects three separate strands of literature.

\subsection{Are REITs real estate?}

Our study is related to the long-standing debate around the extent to which REITs provide exposure to stock market factors relative to the performance of the underlying real estate assets in the REIT's portfolio of investments. ${ }^{5}$ Against the background of low contemporaneous correlations ${ }^{6}$ between REITs and private real estate returns, researchers beginning with Giliberto (1990) emphasize the long-run links between these two sectors of the real estate investment universe. The difference between seemingly weak contemporaneous and stronger long-run linkages produces the notion of lead-lag relationships between the public real estate market (lead) and the private real estate market (lag), where trading is slower and thus more time is needed to adjust prices to new information (Geltner and Kluger, 1998; Ling and Naranjo, 2015). The literature appears to have settled on the consensus that there is a long-run equilibrium association between public and private real estate returns, combined with short-run dynamics between the two markets (Oikarinen, Hoesli, and Serrano, 2011; Wang, 2001). This finding has been confirmed both internationally (Yunus, Hansz, and Kennedy, 2012) and across different property types in the US as well as internationally (Boudry, Coulson, Kallberg, and Liu, 2012; Hoesli and Oikarinen, 2012). However, while the distinction between short-run and long-run linkages between public and private real estate has produced evidence that public real estate securities (REITs) track the underlying real estate markets in the long run, the question about contemporaneous links between REITs and their underlying real estate markets is either firmly rejected in the literature or not independently addressed.

\footnotetext{
5 Hoesli and Oikarinen (2012) review this substantial body of literature in detail.

6 See Carlson, Titman, and Tiu (2010) and Mühlhofer (2013) for a theoretical discussion of the drivers of the association between public and private real estate prices.
} 


\subsection{Determinants of the strength of association between REIT stock returns}

Within this body of research, evidence suggests that the co-movement between REITs and the stock market is time-varying (Clayton and MacKinnon, 2001; Cotter and Stevenson, 2006), increases with stock market volatility (Chong, Miffre, and Stevenson, 2009; Liow, Ho, Ibrahim, and Chen, 2009) and also becomes stronger during downturns. ${ }^{7} \mathrm{~A}$ relevant study in the context of our work is Case, Yang, and Yildirim (2012), who find evidence for a significant structural break in dependence patterns between REITs and stocks in 2001 when REITs were first included in the S\&P stock market indexes. ${ }^{8}$

Little is known about the fundamental drivers of correlation patterns. Exceptions are Liow, Zhou, and Ye (2015), who study the pairwise correlations between international listed real estate securities indexes as a function of market-wide fundamentals, and Alcock and Steiner (2016), who study the firm-level drivers of the correlation between individual REIT stocks and the general stock market. Both studies yield intuitive and robust results, which supports our choice of modelling correlations. However, these studies do not examine pairwise correlations between individual REIT firms, and they do not assess the effects of financial factors, especially index membership, in comparison to those of property-level fundamentals. Specifically, Alcock and Steiner (2016) focus on firm-level measures of return patterns but they only study the sensitivity of individual REITs to variation in the returns on the general stock market. Furthermore, they focus on asymmetric dependence, not overall patterns of association. Our study contributes to this literature by evaluating the relative impact of financial and fundamental factors on the pairwise correlation patterns of REIT stock returns.

\footnotetext{
$\overline{7}$ Specifically, conditional correlations of listed real estate securities with various benchmarks increase in response to negative return shocks (Fei, Ding, and Deng, 2010; Hoesli and Reka, 2013; Liow, 2012; Michayluk, Wilson, and Zurbruegg, 2006; Yang, Zhou, and Leung, 2012). Further, there is evidence of a higher likelihood of jointly negative returns as compared to jointly positive returns between listed real estate market indexes and stock indexes (Dulguerov, 2009; Goorah, 2007; Hoesli and Reka, 2013; Knight, Lizieri, and Satchell, 2005; Zhou and Gao, 2012).

8 They find three distinct periods in REIT-stock correlations, starting with the period leading up to 1991, the date marking the inception of the modern REIT era, followed by the period leading up to 2001 with the inclusion of REITs in broad stock market indexes, and finally the period from 2001 to the end of their study period in late 2008. Correlations were c. $60 \%$ and without trend in the first period, dropped to $30 \%$ in the second period, and gradually regained their earlier levels of $60 \%$ by the end of the third period.
} 


\subsection{The effects of index membership on stock performance}

According to the corporate stock market literature, the effects of index-linked investment are far-reaching. ${ }^{9}$ First, stock prices rise significantly upon index inclusion. These value effects are persistent (Morck and Yang, 2001) and have grown over time (Petajisto, 2011; Wurgler and Zhuravskaya, 2002). After index inclusion, co-movement of stock returns with index-peers increases while the stock typically becomes detached from the rest of the market (Cremers, Petajisto, and Zitzewitz, 2013; Greenwood and Sosner, 2007; Wurgler, 2011), due to the high correlation of in- and outflows of index-linked investment capital (Goetzmann and Massa, 2003).

The evidence on the effects of index-linked investment in real estate is relatively sparse. A group of studies explores the effects of index membership on pricing efficiency. The consensus finding is that REIT market efficiency somewhat improves with index membership (Aguilar, Boudry, and Connolly, 2015; Huang, Su, and Chiu, 2009; Jirasakuldech and Knight, 2005). Another study closely related to our work is Ambrose, Lee, and Peek (2007) who examine the correlation between index-REITs and non-index REITs to estimate spillovers of investor sentiment and market frictions across those firm categories. Our study differs from theirs and complements it in two respects: First, they focus on the index addition event, whereas we focus on the long-term consequences of shared index membership. Second, they study the role of non-fundamental effects in the correlation between index- and non-index firms. We explore the sensitivity of pairwise correlations between index and/or non-index REITs to the effect of fundamentals (property type and geographic exposure). As such, their study speaks to the spillover hypothesis of specifically non-fundamental shocks, whereas our study speaks to the role of property fundamentals in determining the co-movement of REIT returns.

\footnotetext{
9 Wurgler (2011) reviews this literature in relation to, amongst other issues, inclusion effects, persistent changes in value, detachment from non-index peers, sensitivity to crises, and real corporate capital budgeting decisions.
} 


\section{Hypothesis development}

The existing literature on the consequences of index membership for stock performance describes two possible effects, a liquidity effect and a pricing efficiency effect. We use the insights established in this literature to derive our testable hypotheses. The finance literature, on the one hand side, highlights the liquidity effect, which persistently changes the return patterns of index firms, see for instance Cremers, Petajisto, and Zitzewitz (2013); Greenwood and Sosner (2007); Wurgler (2011). According to this literature, index firms attract investment capital from index-linked investors. The in- and outflows of this capital are economically large and highly correlated (Goetzmann and Massa, 2003). Index-linked investors do not distinguish between individual firms but rather allocate capital to all index constituents or all firms that belong to a certain market segment that is part of their investment strategy. When index-linked investment is popular, capital will flow to all index firms in bulk. When index-linked investment falls out of favor, capital will withdraw from all index firms in bulk.

The correlation of index-linked capital flows suggests that, once a firm joins an index or becomes part of a group of firms that is a suitable target for broadly defined investment strategies, the influence of the underlying fundamentals of the firm will become less important for firm performance. For the purpose of our study, this line of reasoning would suggest that when two firms are part of the same index or distinct market segment, their correlation will predominantly be determined by the fact that they form part of the same index or group of firms. By implication, similarities or differences among the fundamentals of those firms may become insignificant in determining the correlation between their returns.

The real estate literature highlights the pricing efficiency effect (Aguilar, Boudry, and Connolly, 2015; Huang, Su, and Chiu, 2009; Jirasakuldech and Knight, 2005). The increased visibility of firms that form part of an index or a distinct segment of the stock market may enhance analyst coverage and attract institutional investors. These two factors are thought to improve information production, facilitating more efficient price discovery on the firm level. However, this literature mostly stops short of identifying 
the channel through which pricing efficiency improves on the firm level. ${ }^{10}$ Is corporatelevel information more accessible and processed more efficiently when firms are part of an index? Or do enhanced analyst coverage and institutional investment improve the assessment of the underlying fundamentals of the firms? We study whether pricing efficiency of REITs improves by assessing the effects of the underlying property fundamentals of REITs on correlation patterns as a function of index membership.

\section{Method}

\subsection{Model background}

We assume that REITs sharing a similar sensitivity to return-generating factors at time $t$ are expected to have similar returns in the future. Consider a multi-factor model that completely describes REIT returns in excess of the risk-free rate:

$R_{i, t}=\sum_{k=1}^{K} \beta_{i, k, t} F_{k, t}+\epsilon_{i, t}$

where $R_{i, t}$ is the total REIT excess return for firm $i$ in period $t, F_{k}$ denotes a returngenerating factor (in excess of the risk-free rate), $\beta_{i, k, t}$ is the sensitivity of firm $i$ to factor $k$ at time $t$, and $\epsilon_{i, t}$ is a random residual with $\mathbb{E}(\epsilon)=0$. Given this return-generating process, we expect firms with similar factor sensitivities at time $t$ to have similar returns at $t+1$ :

$\mathbb{E}_{t}\left[R_{i, t+1}-R_{j, t+1}\right]=\sum_{k=1}^{K}\left(\beta_{i, k, t}-\beta_{j, k, t}\right) \mathbb{E}_{t} F_{k, t+1}$

where $(i, j)$ denote different firms and the random residual cancels out in expectation. If the factor sensitivities are similar, then we expect their returns to be similar. If the factor sensitivities of two firms are identical, their expected returns are also identical.

We further assume that factor sensitivities are a function of firm characteristics. For

$\overline{10}$ With the exception of Aguilar, Boudry, and Connolly (2015), these studies are conducted on the index level, speaking to the efficiency of the REIT market overall. 
instance, we assume that REITs of a similar size have a similar sensitivity to the "size" factor, i.e. a shock that increases the returns of large firms. This assumption is consistent with the literature that computes risk factors based on firm characteristics (Fama and French, 1992, 1993, 1998, 2015). Calculating factors in this way implicitly assumes that firms of a similar size respond in a similar way to the economic shocks that generate differential returns for firms of different sizes. Therefore, we replace the difference in sensitivities in Equation (2) with differences in firm characteristics:

$\mathbb{E}_{t}\left[R_{i, t+1}-R_{j, t+1}\right]=\sum_{k=1}^{K}\left(C_{i, t, k}-C_{j, t, k}\right) \mathbb{E}_{t} F_{k, t+1}$

where $C_{i, k}$ denotes the firm characteristic related to factor $k$, and where we note that firm characteristics and thus factor sensitivities may vary through time.

Estimating Equation (3) implicitly offers a test of whether a factor related to a particular characteristic, $C$, affects stock returns. ${ }^{11}$ Our objective is to evaluate the relative influence of shared index membership and shared fundamentals in determining joint returns. Implementing Equation (3) allows us to determine whether the factor related to each characteristic affects joint returns. In other words, if similarity in a particular characteristic is significant, then the associated factor itself is also significant. For instance, if an event that increases office prices in California affects REITs with similar exposure to this sector/geography in a similar way, then the fundamental economic factor that drives the underlying real estate prices also affects securitized REIT returns.

This approach has a number of advantages in the context of our research objectives. First, it allows us to compare and contrast the influence of financial factors (such as shared index membership) and property-level fundamental factors (shared property sector and geographic exposure) in REIT returns. That means that we are able to speak to the debate about the extent to which REIT returns are driven by financial factors relative to the underlying property performance. Second, by focusing on the similarity of returns, we are able to contribute to the debate about the fundamental drivers of patterns of

$\overline{11}$ We will address the time-varying nature of firm characteristics $C$ when we discuss the empirical implementation of our model in the the next section. 
association in REIT returns. This perspective is particularly useful given that REITs and real estate securities more broadly are often included as a diversifier in multi assetclass portfolios. Therefore, insight into the drivers of correlation patterns among REITs as a function of shared financial versus property-level fundamental factors may produce helpful information for fund portfolio managers considering an allocation to this liquid form of real estate investment. Finally, we can speak directly to the debate about the detachment of index-REIT returns from their non-index peers by including shared index membership as a factor in the empirical implementation of Equation (3) alongside the exposure to underlying property types and geographic regions.

\subsection{Empirical implementation}

In the estimation of Equation (3) we first consider the degree of time-variation in the main factors of interest in our study. The geographic exposure of a REIT can change through two mechanisms, active acquisitions or dispositions, and variation in property price appreciation across different regions. Both of these mechanisms arguably operate slowly. The property type exposure of a REIT and the membership in a stock market index are likely to be even stickier. We address the resulting positive serial correlation in these variables by calculating the differences in characteristics across firms at a low frequency. Consequently, we also replace the period-by-period difference in returns on the left-hand side of Equation (3) with the correlation of returns over a longer time window. ${ }^{12,13}$

We measure the correlation between two REITs using three years of quarterly stock returns. ${ }^{14}$ We match these correlations to the differences in firm characteristics, measured at the year-end prior to the beginning of the next three-year estimation window for the

\footnotetext{
12 Wurgler (2011) notes that beta changes following index inclusion reflect primarily an increased covariance in returns between the included stock and other index members; the standard deviation of returns of the included stock does not change much, hence why we focus on correlations, as a scaled version of covariance.

13 A similar methodology of using pairwise correlations as dependent variables is employed in Bekaert, Harvey, Kiguel, and Wang (2016).

14 The observation frequency raises the question of non synchronous trading, where the random arrival of trades can lead to a systematic underestimation of covariance between return observations sampled at regular intervals (Fisher, 1966). However, Epps (1979) shows that the bias is severe only beyond the inter-hour level. Considering our low observation frequency, we believe that our measurement of covariance is sufficiently accurate.
} 
correlations. We estimate the following model using OLS:

$\operatorname{Corr}_{i, j, t}=\gamma^{\prime}\left(C_{i, t-1}-C_{j, t-1}\right)^{2}+f_{i, j}+d_{t}+u_{i, j, t}$

where $\operatorname{Corr}_{i, j, t}$ is the correlation between the total excess returns of REIT pair $i, j(i<j)$ over the time window $(t: t+2)$ years, $\gamma$ is a column vector of coefficients associated with the characteristics, and $C_{., t-1}$ are vectors of firm characteristics. The power function is applied to the differences in firm characteristics element-by-element. We only include correlations from non-overlapping estimation windows to avoid introducing autocorrelation into our model. As correlations are limited to $[-1,1]$, we apply the Fisher (1915, 1921) transformation so that the variable covers the entire real line. This transformation also has the benefit of linearizing the hypothesized relationship, which is appropriate considering that our empirical model is linear.

Firm characteristics are measured at the end of $t-1$, that is, just before the beginning of the three-year period $(t: t+2)$ over which correlations are computed. Therefore, our inference relates to the predictive content of the firm characteristics for future correlation patterns. The lag also helps mitigate potential simultaneous causality where managers may change firm characteristics, e.g. by adjusting leverage, in response to observing a given dependence pattern. ${ }^{15}$ We square the differences in characteristics in order to ensure that the order in which observations are included in the regression is irrelevant (as the order of variables in computing the correlation is irrelevant). As discussed in the robustness tests section below, we also estimate Equation 4 using absolute differences in characteristics.

Further, $f_{i, j}$ are REIT pair-specific fixed effects ${ }^{16}$ that capture time-invariant unobservable factors specific to a given pair of firms $i, j$ that may be related to the degree of association between their returns, e.g. similarity or differences in management style; $d_{t}$ are time-varying factors common to all REIT pairs that also affect their correlation,

\footnotetext{
$\overline{15}$ Bellemare, Masaki, and Pepinsky (2015) outline the conditions under which lagged explanatory variables address endogeneity.

16 Because of the large number of firm-pairs, we estimate the cross-sectional fixed effects using the procedure in Mundlak (1978).
} 
e.g. similar sensitivities to lending market conditions. Lastly, $u_{i, j, t}$ is the residual. In the empirical estimation we cluster these residuals by firm pair to account for the potential time-series and cross-sectional correlation in residuals.

The main variables of interest are measured as follows: (i) difference in index membership is captured in the form of three categories, one that takes the value of one when two firms in a REIT pair are not members of the same stock market index and one that takes the value of one when both firms are members of an index; the omitted category reflects the case where neither firm is part of an index; (ii) difference in property type exposure is an indicator variable that takes the value of one when two firms in a REIT pair do not share the same property type focus; (iii) difference in geographic exposure is the Euclidean distance between the relative exposure of the two firms in a REIT pair to different mutually exclusive property market regions.

We consider differences in the following firm characteristics as control variables, largely following Fama and French (2015): Firm size (Banz, 1981; Keim, 1983) is the natural logarithm of Market Capitalization. The Market-to-book ratio (Rosenberg, Reid, and Lanstein, 1985; Stattman, 1980) is the Market Value of Assets (Total Assets minus Book Equity plus Market value of Equity) divided by the book value of Total Assets. Given the evidence for the role of leverage in driving REIT returns (Giacomini, Ling, and Naranjo, 2015) and dependence patterns (Alcock and Steiner, 2016), we account for Market leverage (Bhandari, 1988), measured as Total Debt divided by the Market Value of Assets. We further control for the firms' systematic risk as measured by their respective CAPM beta. We include the 6- and 36-month cumulative return as a measure of momentum (DeBondt and Thaler, 1985; Jegadeesh and Titman, 1993). We control for liquidity using turnover, measured as quarterly Trading Volume divided by Common Shares Outstanding (Acharya and Pedersen, 2005; Liu, 2006). Following the investment-based literature on asset pricing, we control for real estate investment growth and profitability, measured as return on average equity (Bond and Xue, 2014).

Finally, note that our approach allows us to assess the impact of a potentially relevant factor driving REIT returns without explicitly computing the return to that factor. This 
is convenient in REITs because returns to some of the arguably most important factors, such as property type and geographic exposure, are difficult to estimate accurately given existing data restrictions, which may well reduce the association between REIT returns and the underlying property in the short run. Our approach avoids the need to compute local property returns and only uses similarity in firm characteristics to examine the significance of a given factor in REIT returns.

The causal effect of index membership could be unidentified if there is omitted variable bias. This is why we include a large set of control variables. The omitted variable may be unobservable, and so we control for firm-pair and time fixed effects in the estimation of Equation (4). The causal effect could also be unidentified if there is reverse causality from correlations to index membership. However, the correlation is measured over the threeyear period after we observe the firm characteristics, mitigating concerns about reverse causality. If high correlations occur because of shared fundamentals that also determine index membership, then there may be simultaneous causality bias. That however is only an issue if the factors that drive both sides of the regression are unobserved, which is fundamentally different in our situation because the factors that determine index membership are known and we control for these characteristics.

\section{Data}

\subsection{REITs and major stock market indexes}

We focus our analysis of index membership on the main Standard and Poors (S\&P) indexes. As Wurgler (2011) notes, the S\&P 500 is among the most important in practice and has been the most studied by researchers, and as such we will focus much of our discussion on the S\&P index family. ${ }^{17}$ The $\mathrm{S} \& \mathrm{P} 500$ is one of the most comprehensive measures of large-cap US equities. Over $\$ 7.8$ trillion of index-linked investment capital is benchmarked to this index, with index assets comprising approximately $\$ 2.2$ trillion of this total. The index includes the 500 leading companies and captures approximately $80 \%$ coverage of available market capitalization. The S\&P MidCap 400 index is a bench-

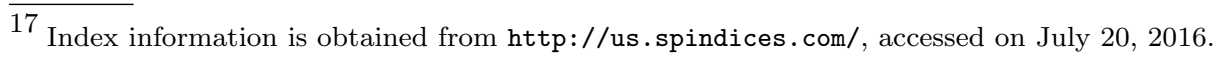


mark for mid-sized companies. The index, which is distinct from the large-cap S\&P 500 , measures the performance of mid-sized companies, reflecting the risk and return characteristics of this market segment. The S\&P SmallCap 600 measures the small-cap segment of the US equity market.

The S\&P Index Methodology stipulates the following six criteria for index additions: (i) Unadjusted company market capitalization of $\$ 5.3$ billion or more for the S\&P 500, $\$ 1.4$ billion to $\$ 5.9$ billion for the S\&P MidCap 400, and $\$ 400$ million to $\$ 1.8$ billion for the S\&P SmallCap 600; (ii) Minimum liquidity requirements in terms of number of shares traded and trading volume to float-adjusted market capitalization; (iii) US domicile; (iv) Minimum public float of $50 \%$ of the stock; (v) GICS sector classification; (vi) Financial viability (the sum of the most recent four consecutive quarters' earnings, FFO for REITs, should be positive as should the most recent quarter). Firms are deleted from the indexes if they are involved in mergers, acquisitions or restructuring such that they no longer meet the inclusion criteria or if they substantially violate one or more of the inclusion criteria. Adjustments to the index composition are made as necessary. As a result, index inclusions are not associated with firm-level fundamental news, thus allowing for an unusually clean estimation setting (Wurgler, 2011).

The S\&P indexes have been open to REITs since October 2001. During our sample period there were 112 REITs in the S\&P500, 45 REITs in the S\&P400 and 41 REITs in the S\&P 600. Most REITs have not been deleted from the indexes, but 39 firms have left the indexes before the end of our study period, and we account for those instances.

\subsection{Data set and descriptive statistics}

We estimate the model outlined above using a sample of publicly listed US equity REITs obtained from the SNL Financial database. We collect total return data and firm characteristics from $S N L$. The risk-free rate is the yield on 3-month US Treasury Bill obtained from the Federal Reserve Bank of St Louis's Economic Database (FRED), to match the quarterly observation frequency of REIT returns. We begin our analysis in 2001, which marks the introduction of REITs into major stock market indexes and represents a fundamental shift in REIT correlation patterns (Ambrose, Lee, and Peek, 
2007; Case, Yang, and Yildirim, 2012). The study period goes through 2015. We adopt an unbalanced panel approach to mitigate survivorship bias (Baum, 2006). Firms enter the sample when they first appear on $S N L$, and exit when they become inactive (acquired/defunct). Entry and exit of firm-pairs in the sample is therefore determined by the entry and exit of the constituent firms in the pair. Our final sample contains 25,909 complete firm-pair observations, generated from an average of approximately 100 firms per observation period (producing $N \times(N-1) / 2 \approx 5000$ firm pairs per estimation period). Given the measurement of pairwise correlations in non-overlapping three-year intervals, we compute correlations based on quarterly stock returns for the following periods: 2001-2003, 2004-2006, 2007-2009, 2010-2012, and 2013-2015. We match these correlations to lagged firm characteristics, measured at the end of 2000, 2003, 2006, 2009, and 2012. In order to mitigate any undue influence of outliers, all continuous firm characteristics and returns are winsorized at the $1^{\text {st }}$ and $99^{\text {th }}$ percentiles.

Property type exposure is defined as the predominant property type of the REIT's assets, as reported on $S N L$. To estimate the geographic exposure of a REIT we consider the area (square footage) and value of each property while it is owned by the REIT. Specifically, we aggregate square footage and value across properties to compute the exposure of each REIT to the four main regions of the US, as defined by Real Capital Analytics $(R C A)$ - North-East, South-East, South-West, and Mid-West. We then compute the percentage exposure to each region relative to the total square footage and value of the REIT's properties. However, calculating geographic exposure by value requires an intermediate step because $S N L$ only records property value at the time of acquisition or refinancing. To estimate property values through time we use the $R C A$ commercial property price indexes by region and property type to interpolate the value evolution of the REIT's properties where necessary. Assuming that the REIT's properties follow the value evolution of their sector/region, we can then compute geographic exposure by value as described. Our empirical results mainly refer to geographic exposure by value.

The geographic exposure calculation by value has the caveat that for some properties $S N L$ has no estimate of value at any point in time. Therefore, the geographic exposure by value of some REITs is based on a subset of the properties for which $S N L$ has value 
information. For our main empirical results, we restrict the estimation to those REITs where we have property value estimates for at least $50 \%$ of the properties. This restriction excludes 9 REIT-quarter observations from the formation of REIT pairs for our final sample. There are also instances of missing observations for the square footage of some properties. Again, for the main empirical results, we restrict our analysis to those REITs for which we have square footage information for at least $50 \%$ of the properties they own. This restriction excludes 1,291 REIT-quarter observations from the final sample. ${ }^{18}$

Table 1 reports the summary statistics for the firm characteristics in the initial sample of 6,700 REIT-quarter observations over the period 2000 to 2015, which, after restrictions, we use to form the REIT pairs for our main analysis. Table 2 reports summary statistics for the 25,909 REIT pair-year observations in our final regression sample.

[Insert Table 1 and Table 2 about here.]

The main firm characteristics we observe during our study period correspond well to the typical values seen in the $S N L$ REIT universe. Table 1 shows that the three-month excess total return over the 3 -month US Treasury Bill is on average 0.02 (total returns are 0.08 and 0.47 for 6 - and 36 -months, respectively). The average market leverage ratio is 0.43 . The average CAPM beta is 0.86 , suggesting that REIT are defensive stocks that carry moderate systematic risk (Chan, Hendershott, and Sanders, 1990; Glascock and Hughes, 1995; Howe and Shilling, 1990). The average market-to-book ratio is 1.27 , and the log of firm size is on average 20.6, consistent with the notion that REITs are on average midsized value stocks. The ratio of stock turnover to shares outstanding is 0.02 per quarter, investment growth averages 0.09 per quarter, and the return on average equity is 0.07 per quarter. Approximately 0.29 of observations are members of one of the S\&P indexes during our study period. The average REIT has an exposure of 0.16 to the Mid-West,

\footnotetext{
18 Our method relies less heavily on estimated property returns than other methods that include returns on underlying property sectors or geographic regions as an independent variable directly. Nevertheless, we also include the difference in exposure based on square footage rather than value. More importantly, errors in the property price or return index that we use arguably have a smaller impact on the geographic exposure than on return calculation. First, if a REIT chooses better properties, then the indexes would underestimate their returns everywhere. This would have no impact on our measure of geographic exposure, but would have a significant impact on any return to underlying properties. Second, when computing the difference in geographic exposure, any errors in valuations are squared, and then differenced, so their impact on the final measure is likely smaller.
} 
0.31 to the North-East, 0.22 to the South-East, and 0.12 to the South-West in any given quarter. In terms of property types, the largest proportion of REITs in our sample are invested in offices (0.24) and retail (0.23), with the remaining sectors (diversified, health care, hotel, residential, and specialty) representing significantly smaller shares.

Table 2 shows that the average correlation of quarterly total returns over three years across REITs in the pairs we study is 0.50 , which translates into a Fisher-transformed correlation of 0.65 . The table also provides insight into the distinguishing features of the REIT pairs. If we consider the average difference in characteristics relative to the average characteristics themselves, we find that the most significant dispersion is in systematic risk, real estate investment growth, long-term (36-month) momentum, and index membership. The finding on investment growth is consistent with the literature which suggests that investment policies (aggressive versus conservative) vary significantly across firms, and more so than many other firm characteristics that have typically been considered in asset pricing, supporting the recent work by Fama and French (2015) and Bond and Xue (2014).

Table 3 shows the pairwise correlation coefficients between the main variables included in our study. We mainly draw on these results to identify any elevated levels of association between the variables in our model that might introduce multicollinearity. Based on the values of the correlation coefficients for the variables in our final sample, we conclude that multicollinearity is not a major concern in our study.

$$
\text { [Insert Table } 3 \text { about here.] }
$$

\section{Results}

\subsection{Main empirical findings}

Table 4 reports our baseline regression results. The dependent variable is the series of transformed 3-year (non-overlapping) correlations between the excess returns of the REIT pairs in the final sample. The independent variables are the squared differences in firm characteristics, index membership, and geographic as well as property type exposure. 
Column (1) controls for year fixed effects, and Column (2) additionally controls for firm pair fixed effects. In the discussion of economic effects below we refer to the estimates from Column (2).

[Insert Table 4 about here.]

We find that shared index membership significantly increases the correlation between pairs REIT returns by a coefficient of 0.155 . Our finding implies that, in economic terms, the effect of both firms being part of an index as opposed to none of them being part of an index increases the (Fisher-transformed) correlation from an average of 0.651 to 0.806 , an increase of almost $25 \%$. To our knowledge, we are the first to quantify these effects in US REITs. Our finding is consistent with the literature on general industrial stocks which suggests that index membership is associated with increased co-movement between index stocks due to the high correlation of index-linked capital flows (Cremers, Petajisto, and Zitzewitz, 2013; Goetzmann and Massa, 2003; Greenwood and Sosner, 2007; Wurgler, 2011). Here we confirm and extend this finding to REIT stocks. In relation to our hypotheses, our results suggest that the liquidity effect of index membership described in the general finance literature matters for REITs, where enhanced visibility and liquidity of index stocks attract more index-linked capital that then flows in and out of the index stocks in a more systematic way than for non-index REITs.

On the other hand, if one REIT in a pair is a member of an index, but the other REIT in the pair is not, then the correlation between their returns increases as well but less strongly than for shared index membership, holding everything else constant. In economic terms, the effect of one firm of the pair being in an index as opposed to none of them increases the (Fisher-transformed) correlation by almost 15\%. To our knowledge, we are the first to compare these two effects of shared index membership and partial index membership in a pair of US REIT stocks. Our findings are qualitatively consistent with the evidence for spillover effects from index stocks to non-index stocks described in Ambrose, Lee, and Peek (2007). While Ambrose, Lee, and Peek (2007) focus primarily on the inclusion event, we extend their evidence to the steady state that evolves over time after the initial inclusion effect. 
Our findings also suggest that the property type exposure as well as the geographic exposure of the REITs in our sample are significant determinants of the correlation patterns between their stock returns, after controlling for the effect of index membership and firm financial characteristics. Specifically, differences in property type exposure and geographic exposure significantly reduce REIT stock return correlations. In economic terms, firms with exposure to completely different property types, as opposed to firm pairs within the same property type, see their (Fisher-transformed) return correlation reduced by almost $18 \%$. Firms with exposure to entirely different geographic regions, as opposed to those firms that hold investments in the same geographic regions, see their return correlation reduced by almost $20 \%$. Our findings suggest that underlying fundamental factors have a strong influence on REIT correlation patterns, whose economic significance is virtually on par with that of index membership. Our findings are consistent with the literature that views REITs as hybrid securities that are part stock, part real estate (Boudry, Coulson, Kallberg, and Liu, 2012). In relation to our hypotheses, our findings suggest that the liquidity effect described above (increasing correlations due to shared index membership) appears to be at play in REIT correlation patterns.

On a qualitative level, our findings speak to the debate about the extent to which REITs provide their investors with exposure to the underlying property fundamentals versus the effects of financial and stock market factors. Our findings suggest that although these financial factors are significant, they do not supersede the effects of fundamentals on joint returns. Given the recent evidence on a long-run equilibrium association between public and private real estate returns, combined with short-run lead/lag relationships between the two markets (Boudry, Coulson, Kallberg, and Liu, 2012; Hoesli and Oikarinen, 2012; Oikarinen, Hoesli, and Serrano, 2011; Wang, 2001; Yunus, Hansz, and Kennedy, 2012), our findings provide fresh insight into the contemporaneous and lasting effects of underlying property market fundamentals on REIT stock returns.

Moreover, our findings contribute to the debate about the drivers of correlation patterns in REITs more generally. Here, we find evidence that increasing differences in firm size, market leverage and systematic risk reduce the correlation between REIT returns, implying that these factors are also significant in determining individual REIT stock 
returns. Our findings relating to size and systematic risk are in line with the established asset pricing literature (Fama and French, 2015). However, in contrast to this literature, we find that the market-to-book ratio is not significantly associated with correlation patterns in REIT returns after controlling for firm-pair fixed effects. This may be evidence that REITs have fewer sources of as well as variation in growth opportunities relative to industrial firms, due to their homogeneous asset base and scope of business activity (Riddiough and Wu, 2009). Further, our finding relating to the significance of REIT leverage confirms earlier evidence that the indebtedness of REITs has consequences for performance (Giacomini, Ling, and Naranjo, 2015; Sun, Titman, and Twite, 2015) and for dependence patterns (Alcock and Steiner, 2016).

Furthermore, we find that differences in short-term momentum (6-month returns) and profitability (ROAE) increase the subsequent correlation between REIT stock returns. Our finding suggests a reversal in short-term stock return and profitability trends, where differences on the firm level in one period converge towards one another in the following period. Further, we find that long-term momentum (36-month returns) and liquidity effects (stock turnover) are not consistently significant in determining REIT correlations in our model after controlling for index membership. This finding is consistent with the view that index-linked investment has effects on performance and liquidity of index stocks, where the index membership variables may capture these effects and drown out more specific measures of performance and liquidity. Lastly, we find that real estate investment growth is insignificant in determining pairwise correlation patterns between REITs, which is consistent with the lack of significance for the market-to-book ratio as real estate investment growth reflects the realization of growth opportunities.

Finally, given our model specification, our results implicitly produce estimates on the returns that are associated with the different return-generating factors, without having to observe the returns on these factors directly in the markets. This interpretation is analogous to the idea of estimating the market risk premium by regressing firm returns on their CAPM beta-the estimated coefficient reflects the equity market risk premium. Given our specification therefore, the coefficient estimates we produce reflect the return premium of, for instance, property type and geographic focus in REIT investments. 
Specifically, our baseline results suggest that a strategy where an investor seeks exposure to REITs focusing on specific property types produces a return premium of almost $12 \%$ over three years (corresponding to $3.8 \%$ per year) and that a strategy aimed at achieving geographic focus across REIT investments produces a return premium of almost $13 \%$ over three years (corresponding to approximately $4.1 \%$ per year) as compared to diversified strategies. Relatively speaking, these return premiums suggest that focus matters for performance, as documented earlier in Capozza and Seguin (1999) and Cronqvist, Högfeldt, and Nilsson (2001), and also that property type focus and geographic focus are similarly effective investment strategies for investors within the US.

\subsection{Index membership and pricing efficiency}

In order to shed more light on the pricing efficiency effect of index membership on REIT returns and its mechanism, we replicate the regressions in Table 4 and add an interaction between the shared index membership variable and the fundamental (geographic and property type) exposure variables. Table 5 reports the estimation results.

[Insert Table 5 about here.]

We find that the interaction between shared index membership and the property type exposure of the REITs in our sample is negative and significant. Our finding implies that conditional on the two firms in a REIT pair being part of the same index, there is a significant impact from differences in property type exposure that reduces the correlation between these two firms above and beyond the main effects of index membership and property type exposure.

In relation to our hypotheses, we interpret this finding as evidence in favor of the pricing efficiency effect of index membership: If two firms are part of an index, and conditional on this membership, their returns become more correlated if the firms are invested in the same property sector. This finding suggests that a firm's property sector becomes a more significant determinant of REIT returns following inclusion of the firms in a major stock market index, implying that the information conveyed in the firms' property sector 
exposure increases in significance in determining correlation patterns, and in that sense pricing efficiency improves through index membership. Our finding is consistent with the existing literature relating pricing efficiency to index membership (Aguilar, Boudry, and Connolly, 2015; Huang, Su, and Chiu, 2009; Jirasakuldech and Knight, 2005). However, our findings extend the existing literature by suggesting that the efficiency gains lie in the improved evaluation of the underlying property type fundamentals and their consequences for REIT performance as returns appear to become more closely associated with the performance of the underlying properties in terms of sector and geography.

We find insignificant evidence for the interaction between shared index membership and geographic exposure: if two firms focus on different geographies, then their returns will be significantly less correlated when they are part of the same stock market index. Our findings suggest that the pricing efficiency gains stem from improved information production and processing in relation to the firms' property sector exposure, not the firms' geographic exposure.

\subsection{Robustness tests}

Tables 6 and 7 replicate our base-case findings using geographic exposure measured by square footage of all properties, rather than value. Square footage as a measure of exposure has the advantage that it does not require computing the value of each property in each period. This area-based measure thus does not rely on interpolated property values. All of our findings are robust to this alternative measure of exposure.

$$
\text { [Insert Tables } 6 \text { and } 7 \text { about here.] }
$$

Furthermore, we test the robustness of our results by controlling for the mean levels of the firm characteristics we include in our regressions. Since index membership is a decision taken largely on the basis of firm characteristics, these effects need to be held constant in order to isolate the impact of the index membership variable on the correlation patterns of interest here. Tables 8 and 9 present the results, which are robust.

[Insert Tables 8 and 9 about here.] 
We also estimate a set of robustness tests around the selection criteria for our sample. First, instead of computing correlations among each pair of REITs over each 3-year non-overlapping estimation window, we employ one- and two-year estimation windows. Our findings remain robust although some significance levels decline for the one-year windows because the correlations are less precisely measured.

Second, our main results use the geographic exposure variable that is calculated based on a restricted sample because we require value/square footage observations for at least $50 \%$ of properties in the REIT's portfolio. For robustness, we relax this restriction to include more firms, but our conclusions remain unchanged.

Further, we also replicate our results on the basis of a broader set of indexes and index ETFs, including the Russell 2000, Wilshire 5000, iShares real estate ETF, and Vanguard REIT ETF. The results are equivalent and our conclusions remain unchanged.

We also note that our definition of property type exposure does not capture fluctuations in REIT portfolio weightings to specific property types. This may be a concern for diversified firms whose portfolio allocations to various sectors may fluctuate significantly over time. For REITs that are listed as belonging to any specific property type on $S N L$, on the basis that this property type represents at least $75 \%$ of the firm's assets, we assume that this property type constantly dominates that firm's portfolio. For robustness, we exclude diversified firms from our analysis. Again, our conclusions remain unchanged. Results for these latter four robustness tests are available upon request.

Finally, we replicate our findings using absolute differences in firm characteristics, rather than the squared differences employed in the main analysis. Although this changes the numerical values of some coefficients on the firm characteristic differences, but all of our results with respect to index membership and geographic as well as property type exposure fully retain their sign and significance.

In order to explore the extent of the effect of index membership beyond the immediate impact on returns, we replace the dependent variable, the correlation between REIT returns, with the correlations of other variables, in particular market leverage, book 
leverage, real estate investment growth and the market-to-book ratio. In unreported results, we find that REITs that have similar geographic/property type exposure and share the same index membership have more correlated market leverage and marketto-book ratios. We find no significant results for the correlation of book leverage and real estate investment growth. Our findings imply that shared index membership affects not only returns but also other firm characteristics that are related to the market value of the firms as determined by investors via stock prices. Beyond those market-driven characteristics, we find little evidence for a convergence in financing or investment choices as a result of shared index membership. This finding suggests that any correlation in returns is primarily driven by asset and management valuation rather than convergence of managerial behavior. Our result therefore suggests that index-linked investment does not necessarily lead to a homogenization of firm policies.

\section{Conclusion}

Do equity REITs that are part of a broad stock market index become more like other stocks, or more like each other and less like other real estate? The literature on the economic consequences of index membership offers no clear prediction, but the question is significant for investors looking to REITs not only for diversification from stocks but specifically as a proxy for exposure to the underlying real estate. We approach the question empirically, using the experience of the 2001 inclusion of REITs into the major $\mathrm{S} \& \mathrm{P}$ indexes as a guide.

We find that shared index membership significantly increases the association of pairwise REIT returns, reflecting the liquidity effect where improved visibility of the stock leads to more capital flows from index-linked investors. We also find evidence that there is a positive interaction between index membership and the underlying property exposure in determining the correlation patterns of REITs, suggesting that the pricing efficiency of the REIT-specific fundamentals improves as a result of index membership.

Our study raises questions regarding the recent announcement by S\&P Dow Jones Indices and MSCI to assign real estate a separate Sector under the GICS system. This 
announcement is hailed by some as the most significant change in the REIT industry in the last 15 years. ${ }^{19}$ Our work suggests that the recent announcement may yield improved pricing efficiency of REIT fundamentals as well as increased visibility for this asset class. An assessment of the GICS event, however, awaits a future study.

In addition, our study raises a number of related questions: What is the role of return correlations in the context of REIT strategies? To the extent that there are M\&A's in REITs, does return correlation predict which firms are most likely to merge? Will managers attempt to diversify their firms' property type and/or geography in order to actively increase or decrease relative correlations? Finally, what is the role of return correlations in the context of hedge fund strategies (i.e. long-short investment strategies)? Are REITs with higher correlations more susceptible to being included in a hedge fund strategy? These questions are left for future research.

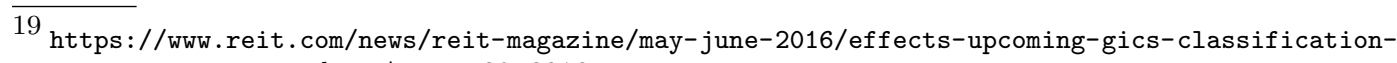
reit-industry, accessed on August 29, 2016.
} 


\section{References}

Acharya, V. V., And L. H. Pedersen (2005): "Asset pricing with liquidity risk," Journal of Financial Economics, 77(2), 375-410.

Aguilar, M., W. I. Boudry, And R. A. Connolly (2015): "The Dynamics of REIT Market Effciency," Working Paper.

Alcock, J., And E. Steiner (2016): "Fundamental Drivers of Dependence in REIT Returns," Journal of Real Estate Finance and Economics, Forthcoming.

Ambrose, B. W., D. W. Lee, And J. Peek (2007): "Comovement after joining an index: spillovers of nonfundamental effects," Real Estate Economics, 35(1), 57-90.

BANZ, R. W. (1981): "The relationship between return and market value of common stocks," Journal of Financial Economics, 9(1), 3-18.

BAum, C. F. (2006): An Introduction to Modern Econometrics, Stata Press books. StataCorp LP, College Station, Texas.

Bekaert, G., C. R. Harvey, A. Kiguel, and X. S. Wang (2016): "Globalization and Asset Returns," Working Paper.

Bellemare, M. F., T. Masaki, and T. B. Pepinsky (2015): "Lagged Explanatory Variables and the Estimation of Causal Effects," MPRA Paper 62350, University Library of Munich, Germany.

BHANDARI, L. C. (1988): "Debt/equity ratio and expected common stock returns: empirical evidence," Journal of Finance, 43(2), 507-528.

Blundell, G., AND C. WARD (1987): "Property portfolio allocation: A multi-factor model," Land Development Studies, 4(2), 145-156.

Bond, S., And C. Xue (2014): "The Cross Section of Expected Real Estate Returns: Insights from Investment-Based Asset Pricing," PREA-RERI Working Paper.

Bond, S. A., AND S. Hwang (2003): "A Measure of Fundamental Volatility in the Commercial Property Market," Real Estate Economics, 31(4), 577-600.

(2007): "Smoothing, Nonsynchronous Appraisal and Cross-Sectional Aggregation in Real Estate Price Indices," Real Estate Economics, 35(3), 349-382.

Boudry, W. I., N. E. Coulson, J. G. Kallberg, And C. H. Liu (2012): "On the Hybrid Nature of REITs," The Journal of Real Estate Finance and Economics, 44(1), 230-249.

Capozza, D. R., And P. J. Seguin (1999): "Focus, Transparency and Value The REIT Evidence," Real Estate Economics, 27(4), 587-619.

Carlson, M., S. Titman, and C. Tiu (2010): "The Returns Linkages for Private and Public Real Estate," RERI Working Paper.

Case, B., Y. Yang, and Y. Yildirim (2012): "Dynamic Correlations Among Asset Classes: REIT and Stock Returns," Journal of Real Estate Finance and Economics, 44(3), 298-318.

Chan, K. C., P. H. Hendershott, and A. B. Sanders (1990): "Risk and return on real estate: Evidence from equity REITs," AREUEA Journal, 18(4), 431-452.

Cho, H., Y. Kawaguchi, and J. D. Shilling (2003): "Unsmoothing Commercial Property Returns: A Revision to Fisher-Geltner-Webb's Unsmoothing Methodology," 
Journal of Real Estate Finance and Economics, 27(3), 393-405.

Cho, Y., S. Hwang, And Y.-K. Lee (2014): "The Dynamics of Appraisal Smoothing," Real Estate Economics, 42(2), 497-529.

Chong, J., J. Miffre, And S. Stevenson (2009): "Conditional correlations and real estate investment trusts," Journal of Real Estate Portfolio Management, 15(2), 173184.

Clayton, J., D. C. Ling, and A. Naranjo (2009): "Commercial real estate valuation: fundamentals versus investor sentiment," Journal of Real Estate Finance and Economics, 38(1), 5-37.

Clayton, J., And G. MacKinnon (2001): "The time-varying nature of the link between REIT, real estate and financial asset returns," Journal of Real Estate Portfolio Management, 7(1), 43-54.

Cotter, J., And S. Stevenson (2006): "Multivariate modelling of daily REIT volatility," Journal of Real Estate Finance and Economics, 32(3), 305-325.

Cremers, M., A. Petajisto, and E. Zitzewitz (2013): "Should Benchmark Indices Have Alpha? Revisiting Performance Evaluation," Critical Finance Review, 2(1), 1-48.

Crongvist, H., P. Högfeldt, And M. Nilsson (2001): "Why Agency Costs Explain Diversification Discounts," Real Estate Economics, 29(1), 85-126.

DeBondt, W. F. M., And R. Thaler (1985): "Does the Stock Market Overreact?," Journal of Finance, 40(3), 793-805.

Dulguerov, M. (2009): "Real estate and portfolio risk: an analysis based on copula functions," Journal of Property Research, 26(3), 265-280.

Edelstein, R. H., And D. C. Quan (2006): "How Does Appraisal Smoothing Bias Real Estate Returns Measurement?," Journal of Real Estate Finance and Economics, 32(1), 41-60.

Epps, T. W. (1979): "Comovements in Stock Prices in the Very Short Run," Journal of the American Statistical Association, 74(366), 291-298.

Fama, E. F., And K. R. French (1992): "The Cross-Section of Expected Stock Returns," Journal of Finance, 47(2), 427-465.

- (1993): "Common risk factors in the returns on stocks and bonds," Journal of Financial Economics, 33(1), 3-56.

- (1998): "Value versus growth: The international evidence," Journal of Finance, 53(6), 1975-1999.

(2015): "A five-factor asset pricing model," Journal of Financial Economics, 116(1), 1-22.

Fei, P., L. Ding, And Y. Deng (2010): "Correlation and volatility dynamics in REIT returns: Performance and portfolio considerations," Journal of Portfolio Management, $36(2), 113-125$.

Fisher, J., D. Geltner, And H. Pollakowski (2007): "A Quarterly Transactionsbased Index of Institutional Real Estate Investment Performance and Movements in Supply and Demand," Journal of Real Estate Finance and Economics, 34(1), 5-33.

Fisher, J. D., D. M. Geltner, And R. B. WebB (1994): "Value indices of commercial real estate: A comparison of index construction methods," Journal of Real Estate 
Finance and Economics, 9(2), 137-164.

Fisher, L. (1966): "Some New Stock-Market Indexes," Journal of Business, 39(1), 191225.

Fisher, R. A. (1915): "Frequency Distribution of the Values of the Correlation Coefficient in Samples from an Indefinitely Large Population," Biometrika, 10(4), 507-521. (1921): "On the "Probable Error" of a Coefficient of Correlation Deduced from a Small Sample," Metron, 1, 3-32.

Gatzlaff, D., And C. Holmes (2013): "Estimating Transaction-Based Price Indices of Local Commercial Real Estate Markets Using Public Assessment Data," Journal of Real Estate Finance and Economics, 46(2), 260-281.

Geltner, D. M. (1991): "Smoothing in appraisal-based returns," Journal of Real Estate Finance and Economics, 4(3), 327-345.

Geltner, D. M. (1993): "Estimating Market Values from Appraised Values without Assuming an Efficient Market," Journal of Real Estate Research, 8(3), 325-346.

Geltner, D. M., And B. Kluger (1998): "REIT-based Pure Play Portfolios: The Case of Property Types," Real Estate Economics, 26(4), 581-612.

Giacomini, E., D. C. Ling, And A. Naranjo (2015): "Leverage and Returns: A CrossCountry Analysis of Public Real Estate Markets," Journal of Real Estate Finance and Economics, 51(2), 125-159.

Giliberto, S. M. (1990): "Equity Real Estate Investment Trusts and Real Estate Returns," Journal of Real Estate Research, 5(2), 259-264.

Glascock, J. L., AND W. T. Hughes (1995): "NAREIT identified exchange listed REITs and their performance characteristics: 1972-1991," Journal of Real Estate Literature, $3(1), 63-83$.

Goetzmann, W. N., And M. Massa (2003): "Index Funds and Stock Market Growth," Journal of Business, 76(1), 1-28.

Goorah, A. (2007): "Real estate management with copulas," Journal of Property Research, 24(4), 289-311.

Greenwood, R. M., And N. Sosner (2007): "Trading patterns and excess comovement of stock returns," Financial Analysts Journal, 63(5), 69-81.

HAURIN, D. (2005): "US commercial real estate indices: transaction-based and constantliquidity indices," in Real estate indicators and financial stability, ed. by B. f. I. Settlements, vol. 21, pp. 232-242. Bank for International Settlements.

Hoesli, M., And E. Oikarinen (2012): "Are REITs real estate? Evidence from international sector level data," Journal of International Money and Finance, 31(7), $1823-1850$.

Hoesli, M., And K. Reka (2013): "Volatility Spillovers, Comovements and Contagion in Securitized Real Estate Markets," Journal of Real Estate Finance and Economics, $47(1), 1-35$.

Howe, J. S., And J. D. Shilling (1990): "REIT Advisor Performance," AREUEA Journal, 18(4), 479-500.

Huang, C.-M., H.-M. Su, And C.-L. Chiu (2009): "REIT market efficiency before and after inclusion in the S\&P 500," Journal of Real Estate Portfolio Management, 
$15(3), 239-250$.

Jegadeesh, N., and S. Titman (1993): "Returns to Buying Winners and Selling Losers: Implications for Stock Market Efficiency," Journal of Finance, 48(1), 65-91.

JiRASAKulDECH, B., AND J. Knight (2005): "Efficiency in the market for REITs: Further evidence," Journal of Real Estate Portfolio Management, 11(2), 123-132.

KeIM, D. B. (1983): "Size-related anomalies and stock return seasonality : Further empirical evidence," Journal of Financial Economics, 12(1), 13-32.

Knight, J., C. Lizieri, And S. SAtchell (2005): "Diversification when it hurts? The joint distributions of real estate and equity markets," Journal of Property Research, $22(4), 309-323$.

Ling, D. C., AND A. NARAnjo (2015): "Returns and Information Transmission Dynamics in Public and Private Real Estate Markets," Real Estate Economics, 43(1), 163-208.

Liow, K. H. (2012): "Co-movements and Correlations Across Asian Securitized Real Estate and Stock Markets," Real Estate Economics, 40(1), 97-129.

Liow, K. H., K. H. D. Ho, M. F. Ibrahim, and Z. Chen (2009): "Correlation and volatility dynamics in international real estate securities markets," Journal of Real Estate Finance and Economics, 39(2), 202-223.

Liow, K. H., X. Zhou, AND Q. Ye (2015): "Correlation Dynamics and Determinants in International Securitized Real Estate Markets," Real Estate Economics, Forthcoming.

LiU, W. (2006): "A liquidity-augmented capital asset pricing model," Journal of Financial Economics, 82(3), 631-671.

Michayluk, D., P. J. Wilson, And R. ZurbruegG (2006): "Asymmetric volatility, correlation and returns dynamics between the US and UK securitized real estate markets," Real Estate Economics, 34(1), 109-131.

Miles, M., D. Hartzell, D. Guilkey, and D. Shears (1991): "A transactionsbased real estate index: Is it possible?," Journal of Property Research, 8(3), 203-217.

Morck, R., AND F. YANG (2001): "The mysterious growing value of S\&P index membership," NBER Working Paper.

Mühlhofer, T. (2013): "Why Do REIT Returns Poorly Reflect Property Returns? Unrealizable Appreciation Gains due to Trading Constraints as the Solution to the Short-Term Disparity," Real Estate Economics, 41(4), 814-857.

Mundlak, Y. (1978): "On the Pooling of Time Series and Cross Section Data," Econometrica, 46(1), 69-85.

Oikarinen, E., M. Hoesli, and C. Serrano (2011): "The Long-Run Dynamics between Direct and Securitized Real Estate," Journal of Real Estate Research, 33(1), 73-104.

Petajisto, A. (2011): "The index premium and its hidden cost for index funds," Journal of Empirical Finance, 18(2), $271-288$.

Quan, D. C., AND J. M. Quigley (1991): "Price Formation and the Appraisal Function in Real Estate Markets," Journal of Real Estate Finance and Economics, 4(2), $127-146$.

Riddiough, T. J., AND Z. Wu (2009): "Financial Constraints, Liquidity Management 
and Investment," Real Estate Economics, 37(3), 447-481.

Rosenberg, B., K. Reid, And R. Lanstein (1985): "Persuasive evidence of market inefficiency," Journal of Portfolio Management, 11(3), 9-17.

Sirmans, C. F., And B. A. Slade (2012): "National Transaction-based Land Price Indices," Journal of Real Estate Finance and Economics, 45(4), 829-845.

Stattman, D. (1980): "Book values and stock returns," Chicago MBA: A Journal of Selected Papers, 4, 25-45.

Sun, L., S. D. Titman, And G. J. Twite (2015): "REIT and Commercial Real Estate Returns: A Postmortem of the Financial Crisis," Real Estate Economics, 43(1), 8-36.

WANG, P. (2001): Econometric Analysis of the Real Estate Market and Investment, Routledge Studies in Business Organizations and Networks Series. Routledge.

Wurgler, J. (2011): "On the Economic Consequences of Index-Linked Investing," in Challenges to Business in the Twenty-First Century, ed. by J. L. Gerald Rosenfeld, and R. Khurana, pp. 20-34. American Academy of Arts and Sciences.

Wurgler, J., AND E. Zhuravskaya (2002): "Does arbitrage flatten demand curves for stocks?," Journal of Business, 75(4), 583-608.

YAng, J., Y. Zhou, AND W. Leung (2012): "Asymmetric Correlation and Volatility Dynamics among Stock, Bond, and Securitized Real Estate Markets," Journal of Real Estate Finance and Economics, 45(2), 491-521.

Yunus, N., J. A. Hansz, And P. J. Kennedy (2012): "Dynamic interactions between private and public real estate markets: Some international evidence," Journal of Real Estate Finance and Economics, 45(4), 1021-1040.

Zhou, J., AND Y. GAO (2012): "Tail Dependence in International Real Estate Securities Markets," Journal of Real Estate Finance and Economics, 45(1), 128-151. 


\section{Figures and Tables}

Descriptive statistics, firm-level

\begin{tabular}{|c|c|c|c|c|c|c|c|}
\hline VARIABLE & Mean & $\mathrm{SD}$ & Min & $\mathrm{P} 25$ & $\mathrm{P} 50$ & P75 & $\operatorname{Max}$ \\
\hline 3-month excess return & 0.022 & 0.155 & -0.561 & -0.054 & 0.023 & 0.101 & 0.615 \\
\hline Market leverage & 0.430 & 0.164 & 0.000 & 0.331 & 0.425 & 0.536 & 0.875 \\
\hline CAPM beta & 0.861 & 2.138 & -6.778 & -0.236 & 0.744 & 1.793 & 8.979 \\
\hline Market-to-book ratio & 1.274 & 0.349 & 0.642 & 1.051 & 1.205 & 1.432 & 2.673 \\
\hline Log of firm size & 20.603 & 1.637 & 15.287 & 19.770 & 20.849 & 21.673 & 23.828 \\
\hline 6-month total return & 0.078 & 0.224 & -0.657 & -0.026 & 0.076 & 0.181 & 1.002 \\
\hline 36-month total return & 0.469 & 0.680 & -0.900 & 0.051 & 0.419 & 0.788 & 3.237 \\
\hline Turnover ratio & 0.020 & 0.018 & 0.000 & 0.008 & 0.014 & 0.025 & 0.106 \\
\hline Real estate investment growth & 0.099 & 0.357 & -0.469 & -0.028 & 0.015 & 0.116 & 3.029 \\
\hline Return on average equity & 0.069 & 0.166 & -0.705 & 0.023 & 0.069 & 0.111 & 0.856 \\
\hline Index membership & 0.287 & 0.452 & 0.000 & 0.000 & 0.000 & 1.000 & 1.000 \\
\hline \multicolumn{8}{|l|}{ Geographic exposure } \\
\hline Mid-West & 0.157 & 0.220 & 0.000 & 0.000 & 0.080 & 0.205 & 1.000 \\
\hline North-East & 0.309 & 0.329 & 0.000 & 0.026 & 0.197 & 0.475 & 1.000 \\
\hline South-East & 0.215 & 0.247 & 0.000 & 0.000 & 0.150 & 0.319 & 1.000 \\
\hline South-West & 0.121 & 0.169 & 0.000 & 0.000 & 0.069 & 0.184 & 1.000 \\
\hline \multicolumn{8}{|l|}{ Property type exposure } \\
\hline Diversified & 0.130 & 0.336 & 0.000 & 0.000 & 0.000 & 0.000 & 1.000 \\
\hline Health Care & 0.073 & 0.261 & 0.000 & 0.000 & 0.000 & 0.000 & 1.000 \\
\hline Hotel & 0.114 & 0.318 & 0.000 & 0.000 & 0.000 & 0.000 & 1.000 \\
\hline Office & 0.239 & 0.426 & 0.000 & 0.000 & 0.000 & 0.000 & 1.000 \\
\hline Residential & 0.145 & 0.352 & 0.000 & 0.000 & 0.000 & 0.000 & 1.000 \\
\hline Retail & 0.226 & 0.418 & 0.000 & 0.000 & 0.000 & 0.000 & 1.000 \\
\hline Specialty & 0.074 & 0.261 & 0.000 & 0.000 & 0.000 & 0.000 & 1.000 \\
\hline
\end{tabular}

Table 1

The table reports the summary statistics for the variables included in our initial sample of $\mathrm{N}=6,700$ firm-quarters used to form firm pairs for the final sample covering the period 2001 to 2015. 3-month excess return is the quarterly total return less the quarter-end yield on 3-month US Treasury Bills. Market leverage is measured as Total Debt divided by the Market Value of Assets (Total Assets minus Book Equity + Market value of Equity). Single-factor CAPM betas are obtained from 3-yearly firm-by-firm regressions of quarterly total returns on the S\&P500 index. Market-to-book ratio is the Market Value of Assets divided by the book value of Total Assets. Firm size is the natural logarithm of the Market Capitalization. 6-month return is the 6-month cumulative total return. 36-month return is the 36-month cumulative total return. Turnover ratio is quarterly Trading volume divided by Common Shares Outstanding. Real estate investment growth measures the rate of investment. Return on average equity measures profitability. Index membership is an indicator variable that takes the value of one when a firm is a member of one of the major S\&P indxes, the S\&P 500, S\&P 400, or S\&P 600. Geographic exposure is shown by asset value and is obtained by aggregating REIT asset values in the major four geographic regions defined by Real Capital Analytics, and dividing by the total value of the REIT's portfolio assets. Missing asset values are interpolated using the Real Capital Analytics indexes. Property sector is as reported by $S N L$. All firm-level data and return data on the firms and the S\&P500 is obtained form SNL Financial. 
Descriptive statistics, firm pairs

\begin{tabular}{lrrrrrrr}
\hline VARIABLE & Mean & SD & Min & P25 & P50 & P75 & Max \\
\hline 3-year correlation & 0.504 & 0.302 & -0.730 & 0.322 & 0.559 & 0.740 & 0.992 \\
3-year correlation (Fisher transformed) & 0.651 & 0.464 & -0.928 & 0.334 & 0.631 & 0.950 & 2.731 \\
Difference in market leverage & 0.049 & 0.075 & 0.000 & 0.004 & 0.020 & 0.062 & 0.739 \\
Difference in CAPM beta & 9.455 & 19.101 & 0.000 & 0.586 & 2.717 & 9.214 & 248.276 \\
Difference in market-to-book ratio & 0.228 & 0.442 & 0.000 & 0.013 & 0.064 & 0.220 & 4.123 \\
Difference in log of firm size & 4.638 & 7.421 & 0.000 & 0.398 & 1.798 & 5.497 & 72.942 \\
Difference in 6-month total return & 0.069 & 0.139 & 0.000 & 0.004 & 0.017 & 0.063 & 1.609 \\
Difference in 36-month total return & 0.573 & 1.261 & 0.000 & 0.036 & 0.165 & 0.536 & 17.114 \\
Difference in turnover ratio & 0.000 & 0.001 & 0.000 & 0.000 & 0.000 & 0.000 & 0.011 \\
Difference in real estate investment growth & 0.273 & 1.180 & 0.000 & 0.003 & 0.020 & 0.086 & 12.235 \\
Difference in ROAE & 0.067 & 0.165 & 0.000 & 0.002 & 0.008 & 0.038 & 2.439 \\
Difference in index membership & 0.321 & 0.467 & 0.000 & 0.000 & 0.000 & 1.000 & 1.000 \\
Difference in property type exposure & 0.836 & 0.370 & 0.000 & 1.000 & 1.000 & 1.000 & 1.000 \\
Difference in geographic exposure & 0.608 & 0.312 & 0.000 & 0.360 & 0.575 & 0.843 & 1.414 \\
\hline \hline
\end{tabular}

Table 2

The table reports the summary statistics for the pairwise squared differences in accounting variables, index membership, and property type and geographic exposure for the $\mathrm{N}=25,909$ firm pair-years in our final regression sample covering the period 2001 to 2015. Variables are defined as follows. Correlations are Fisher transformed correlations based on three years worth of 3-month excess return. Market leverage is measured as Total Debt divided by the Market Value of Assets (Total Assets minus Book Equity + Market value of Equity). Single-factor CAPM betas are obtained from 3-yearly firm-by-firm regressions of quarterly total returns on the S\&P500 index. Market-to-book ratio is the Market Value of Assets divided by the book value of Total Assets. Firm size is the natural logarithm of the Market Capitalization. 6-month return is the 6-month cumulative total return. 36-month return is the 36-month cumulative total return. Turnover ratio is quarterly Trading volume divided by Common Shares Outstanding. Real estate investment growth measures the rate of investment. Return on average equity measures profitability. Index membership is an indicator variable that takes the value of one when a firm is a member of one of the major S\&P indexes, the S\&P 500, S\&P 400, or S\&P 600. Geographic exposure is shown by asset value and is obtained by aggregating REIT asset values in the major four geographic regions defined by Real Capital Analytics, and dividing by the total value of the REIT's portfolio assets. Missing asset values are interpolated using the Real Capital Analytics indexes. Property sector is as reported by $S N L$. All firm-level data and return data on the firms and the S\&P500 is obtained form SNL Financial. 


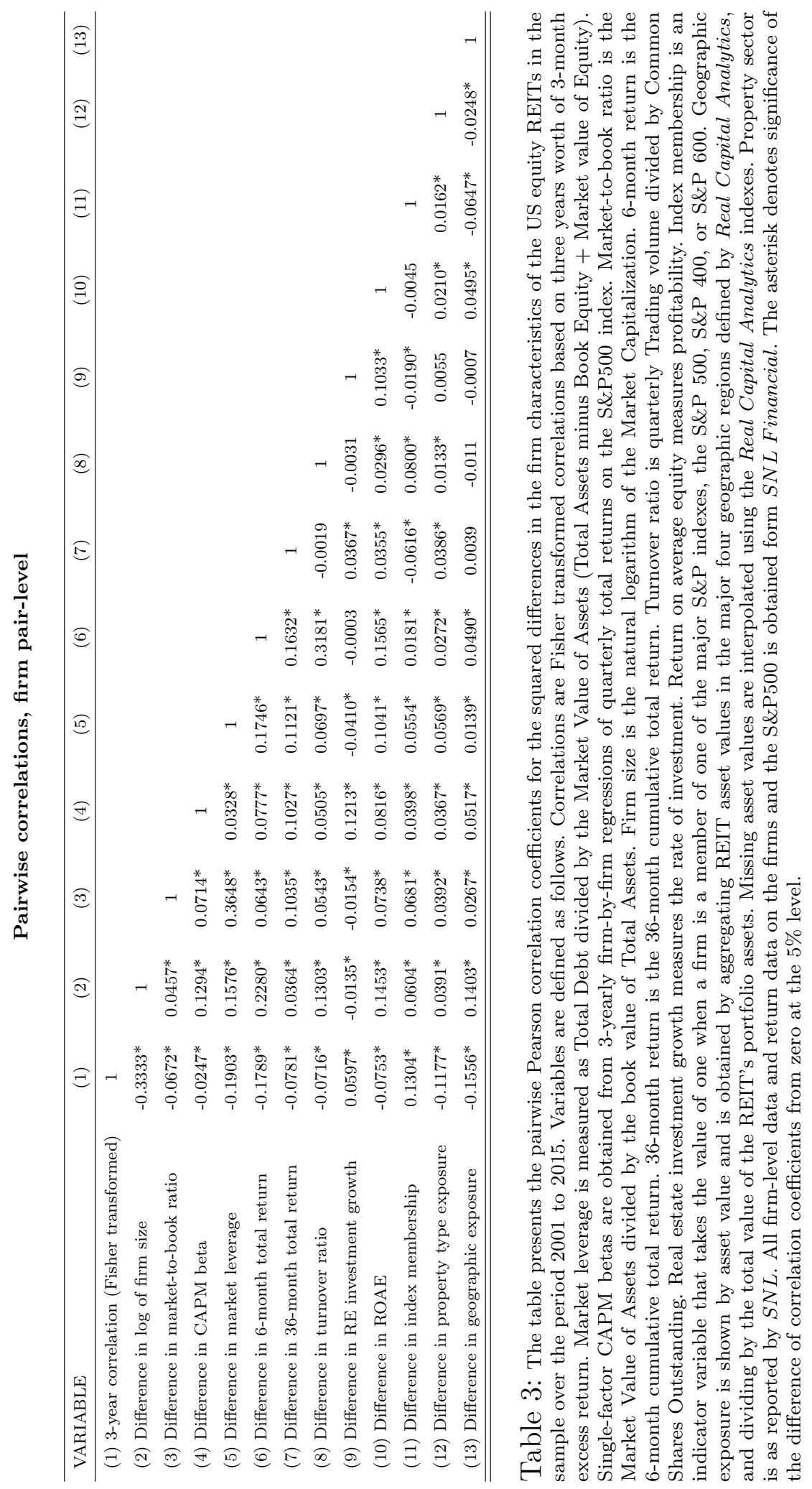


Baseline regression results for 3-year pairwise REIT correlations as a function of differences in index membership, fundamentals and firm-characteristic controls

\begin{tabular}{|c|c|c|c|c|}
\hline \multirow[b]{2}{*}{ VARIABLE } & \multicolumn{2}{|c|}{ (1) } & \multicolumn{2}{|c|}{ (2) } \\
\hline & Coefficient & t-statistic & Coefficient & t-statistic \\
\hline Log of firm size & $-0.016^{* * *}$ & -38.41 & $-0.021^{* * *}$ & -20.87 \\
\hline $\mathrm{MB}$ ratio & $-0.053^{* * *}$ & -8.93 & -0.009 & -1.03 \\
\hline Market leverage & $-0.508^{* * *}$ & -14.74 & $-0.256^{* * *}$ & -4.54 \\
\hline CAPM Beta & $-0.002^{* * *}$ & -15.42 & $-0.002^{* * *}$ & -14.54 \\
\hline 6-month past return & $-0.136 * * *$ & -6.08 & $0.149^{* * *}$ & 6.18 \\
\hline 36-month past return & $-0.016^{* * *}$ & -8.05 & 0.002 & 0.69 \\
\hline Turnover ratio & $-5.023^{*}$ & -2.46 & 1.460 & 0.52 \\
\hline Real estate investment growth & $0.008^{* * *}$ & 3.67 & 0.005 & 1.88 \\
\hline ROAE & $-0.058^{* * *}$ & -4.00 & $0.137^{* * *}$ & 7.18 \\
\hline Both are index members & $0.175^{* * *}$ & 18.22 & $0.155^{* * *}$ & 16.24 \\
\hline One is index member & $0.107^{* * *}$ & 15.18 & $0.097^{* * *}$ & 13.93 \\
\hline Property type exposure & $-0.121^{* * *}$ & -14.78 & $-0.115^{* * *}$ & -14.44 \\
\hline Geographic exposure & $-0.125^{* * *}$ & -13.71 & $-0.126^{* * *}$ & -14.18 \\
\hline Observations & 25,909 & & 25,909 & \\
\hline R-squared & 0.337 & & 0.355 & \\
\hline Year FE & Yes & & Yes & \\
\hline Quasi Firm Pair FE & No & & Yes & \\
\hline
\end{tabular}

Table 4

The table reports the baseline regression results for the three-year (non-overlapping) pairwise correlations of REIT returns as a function of the main variables of interest: (i) difference in index membership is captured in the form of three categories, one that takes the value of one when two firms in a REIT pair are not members of the same stock market index and one that takes the value of one when both firms are members of an index; the omitted category reflects the case where neither firm is part of an index; (ii) difference in property type exposure is an indicator variable that takes the value of one when two firms in a REIT pair do not share the same property type focus; (iii) difference in geographic exposure is the Euclidean distance between the relative exposure of the two firms in a REIT pair to different mutually exclusive property market regions. We control for firm-level characteristics. Column (1) controls for year fixed effects. Column (2) additionally controls for firm pair fixed effects. Because of the large number of firm-pairs, we estimate the cross-sectional fixed effects using the procedure in Mundlak (1978). Right-hand side variables are lagged so that they are measured at the year-end prior to the estimation window for the three-year correlations. Standard errors, for the calculation of t-statistics, are clustered by firm pairs. Significance is indicated as follows: ${ }^{* * *} \mathrm{p}<0.001,{ }^{* *} \mathrm{p}<0.01,{ }^{*} \mathrm{p}<0.05$. 
Additional regression results - with interaction effects

\begin{tabular}{lrrrr}
\hline & \multicolumn{2}{c}{$(1)$} & & \\
VARIABLE & Coefficient & t-statistic & Coefficient & t-statistic \\
\hline & & & & \\
Log of firm size & $-0.016^{* * *}$ & -38.47 & $-0.021^{* * *}$ & -20.88 \\
MB ratio & $-0.053^{* * *}$ & -8.87 & -0.009 & -0.97 \\
Market leverage & $-0.509^{* * *}$ & -14.80 & $-0.257^{* * *}$ & -4.55 \\
CAPM Beta & $-0.002^{* * *}$ & -15.45 & $-0.002^{* * *}$ & -14.57 \\
6-month past return & $-0.135^{* * *}$ & -6.03 & $0.150^{* * *}$ & 6.19 \\
36-month past return & $-0.016^{* * *}$ & -8.11 & 0.002 & 0.63 \\
Turnover ratio & $-5.009^{*}$ & -2.45 & 1.546 & 0.55 \\
Real estate investment growth & $0.008^{* * *}$ & 3.69 & 0.005 & 1.90 \\
ROAE & $-0.058^{* * *}$ & -4.04 & $0.137^{* * *}$ & 7.17 \\
Both are index members & $0.242^{* * *}$ & 8.69 & $0.222^{* * *}$ & 7.99 \\
One is index member & $0.107^{* * *}$ & 15.18 & $0.096^{* * *}$ & 13.93 \\
Property type exposure & $-0.106^{* * *}$ & -12.33 & $-0.101^{* * *}$ & -12.00 \\
Geographic exposure & $-0.130^{* * *}$ & -13.34 & $-0.132^{* * *}$ & -13.83 \\
Both index members $\times$ Geographic exposure & 0.040 & 1.53 & 0.040 & 1.56 \\
Both index members $\times$ Property type exposure & $-0.108^{* * *}$ & -4.79 & $-0.107^{* * *}$ & -4.78 \\
Observations & & & & \\
R-squared & 25,909 & & 25,909 & \\
Year FE & 0.338 & & 0.356 & Yes \\
Quasi Firm Pair FE & Yes & & & \\
\hline \hline
\end{tabular}

Table 5

The table reports the additional regression results for the three-year (non-overlapping) pairwise correlations of REIT returns as a function of the main variables of interest: (i) difference in index membership is captured in the form of three categories, one that takes the value of one when two firms in a REIT pair are not members of the same stock market index and one that takes the value of one when both firms are members of an index; the omitted category reflects the case where neither firm is part of an index; (ii) difference in property type exposure is an indicator variable that takes the value of one when two firms in a REIT pair do not share the same property type focus; (iii) difference in geographic exposure is the Euclidean distance between the relative exposure of the two firms in a REIT pair to different mutually exclusive property market regions. We control for firm-level characteristics. In contrast to Table 4, we additionally include an interaction term between shared index membership and geographic as well as property type exposure, respectively. Column (1) controls for year fixed effects. Column (2) additionally controls for firm pair fixed effects. Because of the large number of firm-pairs, we estimate the cross-sectional fixed effects using the procedure in Mundlak (1978). Right-hand side variables are lagged so that they are measured at the year-end prior to the estimation window for the three-year correlations. Standard errors, for the calculation of t-statistics, are clustered by firm pairs. Significance is indicated as follows: *** $\mathrm{p}<0.001,{ }^{* *} \mathrm{p}<0.01,{ }^{*} \mathrm{p}<0.05$. 
Robustness test results - with area-based (square footage) exposure

\begin{tabular}{|c|c|c|c|c|}
\hline \multirow[b]{2}{*}{ VARIABLE } & \multicolumn{2}{|c|}{ (1) } & \multicolumn{2}{|c|}{ (2) } \\
\hline & Coefficient & t-statistic & Coefficient & t-statistic \\
\hline Log of firm size & $-0.016^{* * *}$ & -28.40 & $-0.027^{* * *}$ & -16.13 \\
\hline $\mathrm{MB}$ ratio & $-0.045^{* * *}$ & -5.10 & $0.036^{* *}$ & 2.62 \\
\hline Market leverage & $-0.704^{* * *}$ & -13.61 & $-0.418^{* * *}$ & -5.22 \\
\hline CAPM Beta & $-0.003^{* * *}$ & -10.59 & $-0.003^{* * *}$ & -11.16 \\
\hline 6-month past return & $0.066^{*}$ & 2.11 & $0.420^{* * *}$ & 12.13 \\
\hline 36-month past return & $-0.023^{* * *}$ & -7.86 & $0.008^{*}$ & 2.18 \\
\hline Turnover ratio & $-17.605^{* * *}$ & -6.04 & $-12.798^{* *}$ & -2.97 \\
\hline Real estate investment growth & $0.010^{* * *}$ & 3.38 & $0.009^{* *}$ & 2.63 \\
\hline ROAE & $-0.052^{*}$ & -2.41 & $0.097^{* *}$ & 2.70 \\
\hline Both are index members & $0.177^{* * *}$ & 13.31 & $0.154^{* * *}$ & 11.53 \\
\hline One is index member & $0.104^{* * *}$ & 9.81 & $0.091^{* * *}$ & 8.91 \\
\hline Property type exposure & $-0.099 * * *$ & -10.56 & $-0.093^{* * *}$ & -10.09 \\
\hline Geographic exposure (area) & $-0.125^{* * *}$ & -10.80 & $-0.131 * * *$ & -11.47 \\
\hline Observations & 11,943 & & 11,943 & \\
\hline R-squared & 0.374 & & 0.400 & \\
\hline Year FE & Yes & & Yes & \\
\hline Quasi Firm Pair FE & No & & Yes & \\
\hline
\end{tabular}

Table 6

The table reports the robustness test results for the three-year (non-overlapping) pairwise correlations of REIT returns as a function of the main variables of interest: (i) difference in index membership is captured in the form of three categories, one that takes the value of one when two firms in a REIT pair are not members of the same stock market index and one that takes the value of one when both firms are members of an index; the omitted category reflects the case where neither firm is part of an index; (ii) difference in property type exposure is an indicator variable that takes the value of one when two firms in a REIT pair do not share the same property type focus; (iii) difference in geographic exposure is the Euclidean distance between the relative exposure of the two firms in a REIT pair to different mutually exclusive property market regions. We control for firm-level characteristics. In contrast to Table 4, geographic exposure is calculated based on the area (square footage) of the properties in the REIT's portfolio. Column (1) controls for year fixed effects. Column (2) additionally controls for firm pair fixed effects. Because of the large number of firm-pairs, we estimate the cross-sectional fixed effects using the procedure in Mundlak (1978). Right-hand side variables are lagged so that they are measured at the year-end prior to the estimation window for the three-year correlations. Standard errors, for the calculation of t-statistics, are clustered by firm pairs. Significance is indicated as follows: ${ }^{* * *} \mathrm{p}<0.001,{ }^{* *} \mathrm{p}<0.01,{ }^{*} \mathrm{p}<0.05$. 
Robustness test results - with area-based (square footage) exposure and interactions

\begin{tabular}{|c|c|c|c|c|}
\hline \multirow[b]{2}{*}{ VARIABLE } & \multicolumn{2}{|c|}{ (1) } & \multicolumn{2}{|c|}{$(2)$} \\
\hline & Coefficient & t-statistic & Coefficient & t-statistic \\
\hline Log of firm size & $-0.016^{* * *}$ & -28.45 & $-0.027^{* * *}$ & -16.18 \\
\hline MB ratio & $-0.045^{* * *}$ & -5.07 & $0.037^{* *}$ & 2.71 \\
\hline Market leverage & $-0.707^{* * *}$ & -13.65 & $-0.422^{* * *}$ & -5.27 \\
\hline CAPM Beta & $-0.003^{* * *}$ & -10.62 & $-0.003^{* * *}$ & -11.19 \\
\hline 6-month past return & $0.066^{*}$ & 2.10 & $0.420^{* * *}$ & 12.13 \\
\hline 36-month past return & $-0.023^{* * *}$ & -7.83 & $0.008^{*}$ & 2.19 \\
\hline Turnover ratio & $-17.551^{* * *}$ & -6.03 & $-12.811^{* *}$ & -2.98 \\
\hline Real estate investment growth & $0.010^{* * *}$ & 3.40 & $0.009^{* *}$ & 2.64 \\
\hline ROAE & $-0.053^{*}$ & -2.44 & $0.097^{* *}$ & 2.72 \\
\hline Both are index members & $0.245^{* * *}$ & 7.98 & $0.219 * * *$ & 7.17 \\
\hline One is index member & $0.104^{* * *}$ & 9.84 & $0.092^{* * *}$ & 8.94 \\
\hline Property type exposure & $-0.088^{* * *}$ & -8.71 & $-0.082^{* * *}$ & -8.20 \\
\hline Geographic exposure (area) & $-0.124^{* * *}$ & -9.97 & $-0.131^{* * *}$ & -10.69 \\
\hline Both index members $\times$ Geographic exposure (area) & -0.014 & -0.43 & -0.006 & -0.19 \\
\hline Both index members $\times$ Property type exposure & $-0.080^{* * *}$ & -3.40 & $-0.083^{* * *}$ & -3.58 \\
\hline Observations & 11,943 & & 11,943 & \\
\hline R-squared & 0.375 & & 0.400 & \\
\hline Year FE & Yes & & Yes & \\
\hline Quasi Firm Pair FE & No & & Yes & \\
\hline
\end{tabular}

Table 7

The table reports the additional regression results for the three-year (non-overlapping) pairwise correlations of REIT returns as a function of the main variables of interest: (i) difference in index membership is captured in the form of three categories, one that takes the value of one when two firms in a REIT pair are not members of the same stock market index and one that takes the value of one when both firms are members of an index; the omitted category reflects the case where neither firm is part of an index; (ii) difference in property type exposure is an indicator variable that takes the value of one when two firms in a REIT pair do not share the same property type focus; (iii) difference in geographic exposure is the Euclidean distance between the relative exposure of the two firms in a REIT pair to different mutually exclusive property market regions. We control for firm-level characteristics. In contrast to Table 5, geographic exposure is calculated based on the area (square footage) of the properties in the REIT's portfolio. Column (1) controls for year fixed effects. Column (2) additionally controls for firm pair fixed effects. Because of the large number of firm-pairs, we estimate the cross-sectional fixed effects using the procedure in Mundlak (1978). Right-hand side variables are lagged so that they are measured at the year-end prior to the estimation window for the three-year correlations. Standard errors, for the calculation of t-statistics, are clustered by firm pairs. Significance is indicated as follows: ${ }^{* * *} \mathrm{p}<0.001,{ }^{* *} \mathrm{p}<0.01,{ }^{*} \mathrm{p}<0.05$. 
Robustness test results - controlling for levels of characteristics

\begin{tabular}{|c|c|c|c|c|}
\hline \multirow[b]{2}{*}{ VARIABLE } & \multicolumn{2}{|c|}{ (1) } & \multicolumn{2}{|c|}{$(2)$} \\
\hline & Coefficient & t-statistic & Coefficient & t-statistic \\
\hline Mean MB ratio & $-0.074^{* * *}$ & -8.70 & $-0.076^{* * *}$ & -9.08 \\
\hline Mean turnover ratio & $3.537 * * *$ & 23.96 & $3.469^{* * *}$ & 23.88 \\
\hline Mean reinvestment growth & 0.002 & 0.23 & -0.007 & -0.91 \\
\hline Mean ROAE & $0.114^{* * *}$ & 11.38 & $0.114^{* * *}$ & 11.55 \\
\hline Mean arket leverage & $-0.085^{* * *}$ & -5.99 & $-0.089 * * *$ & -6.16 \\
\hline Mean CAPM Beta & $-0.002^{*}$ & -2.46 & $-0.002^{*}$ & -2.09 \\
\hline Mean 6-month past return & $0.027^{* *}$ & 2.61 & 0.011 & 1.10 \\
\hline Mean 36-month past return & $0.061^{* * *}$ & 13.87 & $0.062^{* * *}$ & 14.26 \\
\hline Both are index members & $0.198^{* * *}$ & 7.23 & $0.177^{* * *}$ & 6.50 \\
\hline One is index member & $0.088^{* * *}$ & 12.91 & $0.078^{* * *}$ & 11.67 \\
\hline Property type exposure & $-0.105^{* * *}$ & -13.07 & $-0.100 * * *$ & -12.73 \\
\hline Geographic exposure & $-0.099^{* * *}$ & -10.75 & $-0.103^{* * *}$ & -11.46 \\
\hline Both index members $\times$ Geographic exposure & $0.064^{*}$ & 2.44 & $0.067^{* *}$ & 2.60 \\
\hline Both index members $\times$ Property type exposure & $-0.116^{* * *}$ & -5.25 & $-0.114^{* * *}$ & -5.22 \\
\hline Observations & 25,909 & & 25,909 & \\
\hline R-squared & 0.365 & & 0.382 & \\
\hline Year FE & Yes & & Yes & \\
\hline Quasi Firm Pair FE & No & & Yes & \\
\hline
\end{tabular}

Table 8

The table reports the robustness test results for the three-year (non-overlapping) pairwise correlations of REIT returns as a function of the main variables of interest: (i) difference in index membership is captured in the form of three categories, one that takes the value of one when two firms in a REIT pair are not members of the same stock market index and one that takes the value of one when both firms are members of an index; the omitted category reflects the case where neither firm is part of an index; (ii) difference in property type exposure is an indicator variable that takes the value of one when two firms in a REIT pair do not share the same property type focus; (iii) difference in geographic exposure is the Euclidean distance between the relative exposure of the two firms in a REIT pair to different mutually exclusive property market regions. We control for firm-level characteristics but coefficients are not shown. In contrast to Table 5, we additionally control for the mean levels of the firm characteristic controls in the firm pairs in our sample. Column (1) controls for year fixed effects. Column (2) additionally controls for firm pair fixed effects. Because of the large number of firm-pairs, we estimate the cross-sectional fixed effects using the procedure in Mundlak (1978). Right-hand side variables are lagged so that they are measured at the year-end prior to the estimation window for the three-year correlations. Standard errors, for the calculation of t-statistics, are clustered by firm pairs. Significance is indicated as follows: $* * * \mathrm{p}<0.001, * *$ $\mathrm{p}<0.01,{ }^{*} \mathrm{p}<0.05$. 
Robustness test results - with area-based (square footage) exposure and controlling for levels of characteristics

\begin{tabular}{|c|c|c|c|c|}
\hline \multirow[b]{2}{*}{ VARIABLE } & \multicolumn{2}{|c|}{ (1) } & \multicolumn{2}{|c|}{$(2)$} \\
\hline & Coefficient & t-statistic & Coefficient & t-statistic \\
\hline Mean MB ratio & $-0.067 * * *$ & -5.47 & $-0.068^{* * *}$ & -5.83 \\
\hline Mean turnover ratio & $2.606^{* * *}$ & 12.39 & $2.487^{* * *}$ & 12.22 \\
\hline Mean reinvestment growth & 0.000 & 0.01 & -0.015 & -1.38 \\
\hline Mean ROAE & $0.074^{* * *}$ & 4.76 & $0.079^{* * *}$ & 5.17 \\
\hline Mean arket leverage & $-0.156^{* * *}$ & -7.48 & $-0.185^{* * *}$ & -8.66 \\
\hline Mean CAPM Beta & $-0.004^{* *}$ & -2.72 & -0.002 & -1.34 \\
\hline Mean 6-month past return & $0.055^{* * *}$ & 3.56 & $0.045^{* *}$ & 2.94 \\
\hline Mean 36-month past return & $0.067^{* * *}$ & 9.91 & $0.064^{* * *}$ & 9.71 \\
\hline Both are index members & $0.222^{* * *}$ & 7.38 & $0.192^{* * *}$ & 6.42 \\
\hline One is index member & $0.089^{* * *}$ & 8.65 & $0.076^{* * *}$ & 7.61 \\
\hline Property type exposure & $-0.087 * * *$ & -9.14 & $-0.081^{* * *}$ & -8.68 \\
\hline Geographic exposure based (area) & $-0.099 * * *$ & -8.25 & $-0.106^{* * *}$ & -8.97 \\
\hline Both index members $\times$ Geographic exposure (area) & -0.010 & -0.30 & 0.001 & 0.04 \\
\hline Both index members $\times$ Property type exposure & $-0.092^{* * *}$ & -4.00 & $-0.095^{* * *}$ & -4.18 \\
\hline Observations & 11,943 & & 11,943 & \\
\hline R-squared & 0.397 & & 0.422 & \\
\hline Year FE & Yes & & Yes & \\
\hline Quasi Firm Pair FE & No & & Yes & \\
\hline
\end{tabular}

Table 9

The table reports the robustness test results for the three-year (non-overlapping) pairwise correlations of REIT returns as a function of the main variables of interest: (i) difference in index membership is captured in the form of three categories, one that takes the value of one when two firms in a REIT pair are not members of the same stock market index and one that takes the value of one when both firms are members of an index; the omitted category reflects the case where neither firm is part of an index; (ii) difference in property type exposure is an indicator variable that takes the value of one when two firms in a REIT pair do not share the same property type focus; (iii) difference in geographic exposure is the Euclidean distance between the relative exposure of the two firms in a REIT pair to different mutually exclusive property market regions. We control for firm-level characteristics but coefficients are not shown. In contrast to Table 5, we additionally control for the mean levels of the firm characteristic controls in the firm pairs in our sample. Further, geographic exposure is calculated based on the area (square footage) of the properties in the REIT's portfolio. Column (1) controls for year fixed effects. Column (2) additionally controls for firm pair fixed effects. Because of the large number of firm-pairs, we estimate the cross-sectional fixed effects using the procedure in Mundlak (1978). Right-hand side variables are lagged so that they are measured at the year-end prior to the estimation window for the three-year correlations. Standard errors, for the calculation of t-statistics, are clustered by firm pairs. Significance is indicated as follows: ${ }^{* * *} \mathrm{p}<0.001,{ }^{* *}$ $\mathrm{p}<0.01,{ }^{*} \mathrm{p}<0.05$. 